\title{
Party Structures and Organization Building in Africa
}

\author{
Sarah J Lockwood \\ Columbia University, USA; University of Cape Town, South Africa \\ Matthias Krönke \\ University of Cape Town, South Africa \\ Robert Mattes \\ University of Strathclyde, UK; University of Cape Town, South Africa
}

\begin{abstract}
Political parties are a vital element in the quality of representative democracy, playing a crucial role in mobilization, competition, governance and accountability. Despite their importance, however, we currently know relatively little about how political parties in Africa are organized, with most evidence restricted to journalistic accounts, or country-specific scholarly accounts. This special issue, which comes out of a conference on political parties held at the University of Cape Town, takes a closer look at the development of party structures and organization across the continent. It seeks to answer a number of critical questions including: What affects the organizational structure of parties? How do party primaries affect party-building and electoral success? And what effect does the shrinking of open political space have on the ways in which parties organize? Taken as a whole, this issue brings together established and emerging scholars, to systematically explore, for the first time, what party organization looks like on the African continent, and how it affects critical issues of governance, mobilization, and accountability.
\end{abstract}

\section{Author Biographies}

Sarah J. Lockwood (PhD Harvard University, 2019) is a postdoctoral research scholar at Columbia University, and a research affiliate at the Institute for Democracy, Citizenship and Public Policy in Africa at the University of Cape Town. Her research interests include protest brokers, social movements, political parties and democratic accountability.

Matthias Krönke is a PhD candidate at the University of Cape Town (UCT), and a researcher at the Institute for Democracy, Citizenship and Public Policy in Africa at UCT. His research interests include political parties, judicial politics, state bureaucracies, and democratic accountability. 
Robert Mattes (PhD, University of Illinois, Urbana-Champaign 1992) is Professor at the University of Strathclyde and Honorary Professor in the Institute for Democracy, Citizenship and Public Policy in Africa at the University of Cape Town. He is also a co-founder of and Senior Advisor to Afrobarometer. His research focusses on the intersection of public opinion, political institutions and democratization in Africa. 


\title{
Party Structures and Organization Building in Africa
}

\begin{abstract}
Political parties are a vital element in the quality of representative democracy, playing a crucial role in mobilization, competition, governance and accountability. Despite their importance, however, we currently know relatively little about how political parties in Africa are organized, with most evidence restricted to journalistic accounts, or country-specific scholarly accounts. This special issue, which comes out of a conference on political parties held at the University of Cape Town, takes a closer look at the development of party structures and organization across the continent. It seeks to answer a number of critical questions including: What affects the organizational structure of parties? How do party primaries affect party-building and electoral success? And what effect does the shrinking of open political space have on the ways in which parties organize? Taken as a whole, this issue brings together established and emerging scholars, to systematically explore, for the first time, what party organization looks like on the African continent, and how it affects critical issues of governance, mobilization, and accountability.
\end{abstract}

\section{Introduction}

Political parties are an essential part of modern democracy, and lie at the heart of democratic

political systems around the world. Indeed, Schattschneider (1942: 1) famously claimed that 
"political parties created democracy, and...democracy is unthinkable save in terms of parties." While, as Aldrich (1995) notes, Schattschneider's claim might be somewhat overstated, the fact remains that effective political parties play a number of vital roles in modern democracies shaping competition for elected office, providing a key means of holding elected officials accountable, and aggregating the interests of citizens.

Despite their importance, however, over 25 years after the fourth wave of democracy reintroduced multipartyism across much of Africa (Berg-Schlosser, 2009; Doorenspleet, 2000), research on African parties remains "embryonic" at best (Cooper, 2018: 195). While studies of parties in other regions of the world fill the pages of numerous academic journals, books, and edited volumes, those in Africa are often dismissed, with limited evidence, as weak, ineffective, and inconsequential, and - as a result - somehow unworthy of study (see Cooper, 2018).

As the articles in this special issue show, however, African parties are anything but inconsequential. Like their counterparts elsewhere, they contest elections, engage with citizens, recruit, train and socialize political actors, hold incumbents accountable (albeit to varying degrees), organize creatively in response to changing and challenging circumstances, and affect citizens' views of the democratic system. Far from being simply the "weak link in the chain of elements that together make for a democratic state" (Randall and Svåsand, 2002: 31), therefore, parties in Africa are actually an important part of political activity on the continent, and a better understanding of their activities, behavior and organization is essential.

In this issue, we contribute to this work by presenting a collection of papers that come out of a conference on party organization in Africa held at the University of Cape Town in 2018. The studies in this special issue explore some of the key aspects of party organization - including local level party presence, party-building, and intra-party democracy - and draw on a wealth of 
new empirical data to show the important role that parties play in contemporary African politics. Taken as a whole, these papers bring together established and emerging scholars from Africa, North America and Europe, to systematically explore, for the first time, what party organization looks like on the African continent, and how it affects critical issues of governance, mobilization, and accountability.

\section{African Parties in the Literature}

As Cheeseman (2018) notes, the study of formal institutions, including parties, in Africa has "waxed and waned with the fortunes of African democracy" (4). As independent states replaced colonial ones in the 1960 s, for example, a significant, though largely descriptive, literature came into being, focused on understanding the new institutions that were being developed, as well as the impact of older colonial or pre-colonial ones (Coleman and Rosberg, 1964; Hodkin, 1961; see, for example, Leys, 1967; Mackintosh, 1962; Schachter-Morgenthau, 1964; Sklar, 1963). As democracy retreated across the continent in the 1970s and 1980s, however, the focus in the literature shifted, with scholars scrambling to understand these new events, and quick to blame weak institutions for the failure of the democratic project. Indeed, for several decades, the continent was assumed to be effectively "institutionless," lacking effective political organizations such as parties, and entirely reliant on informal institutions such as patronage and traditional authority to shape political behavior (Chabal and Daloz, 1999; Cheeseman, 2018). With few exceptions, therefore, parties and other formal institutions were sidelined in academic research over this period, in favor of concepts such as neopatrimonialism and clientelism, and a 
focus on big men and regimes of personal rule (Cheeseman, 2018; Jackson and Rosberg, 1982; Médard, 1982). ${ }^{1}$

With the return of multiparty democracy in the 1990s, however, research on formal institutions began to proliferate once again (Cheeseman, 2018). From Riedl's (2014) work examining institutional continuities across the continent, to Posner's $(2004,2005)$ work showing the ways in which multiparty democracy shapes ethnic and linguistic identities, a new body of literature began to flourish - focused on the myriad ways in which formal institutions work and evolve, and the impact they have on development and democracy. ${ }^{2}$

Within this burgeoning literature, however, parties in Africa remain woefully understudied, in large part because they are often still seen as weak and ineffectual, decried for their perceived reliance on "the personal fortunes of 'big men'," rather than formal rules and organizations, and dismissed as the "weakest link" in the democratization process (Carothers, 2006). As Cooper (2018) notes, "African parties...have a bad reputation" (191), and this reputation has led to their frequent sidelining in studies of both formal institutions on the African continent, and the comparative literature on political parties around the world.

Increasingly, however, we are finding evidence that these long-held views of African parties need re-thinking. Authors such as Arriola (2012), Basedau \& Stroh (2008), Elischer (2013) LeBas (2011), Pitcher (2012), Resnick (2012) and Wahman (2017), for example, have all shown that there is significant variation in the types of parties that exist across Africa, in terms of their strength, levels of institutionalization and linkages with citizens. Far from being uniformly weak and unimportant, therefore, African parties actually display an impressive range of forms

\footnotetext{
${ }^{1}$ Exceptions to this trend typically focused on those few political systems that were seen to be at least somewhat effective, such as Tanzania, Zambia and South Africa, where strong one-party or hegemonic states developed. See, for example, Barkan (1979), Bates (1971), Bratton (1980), Gertzel et al (1984), and Frankel (1980).

${ }^{2}$ See Cheeseman (2018) for a fuller discussion of this new literature on institutions in Africa.
} 
and types, with potentially critical implications for democracy and development. Moving beyond typology, moreover, a nascent set of studies explore important relationships between political party behavior and democratic outcomes, showing that African parties do play important roles in democratic consolidation (Randall and Svåsand, 2002), quality (Osei, 2013), accountability and representation (Arriola et al., 2021).

African parties are not uniformly weak and ineffective, therefore, and the evidence suggests that we need to study them more closely - moving beyond easy generalizations and sweeping assumptions, to explore the complexities and realities of party organization and behavior on the ground.

\section{This Issue}

In this special issue, we contribute to this work by bringing together a diverse set of scholars from Africa, North America and Europe to explore a range of important questions that remain understudied by the literature, and to set the stage for a new agenda on party organization.

Following this introduction, the issue begins with an article by Krönke, Lockwood and Mattes ("Party Footprints in Africa: Measuring Local Party Presence Across the Continent"), in which the authors explore the local level organization of parties across the continent, and develop a new way to measure party presence at the local level.

Local level party presence is a critical aspect of party organization, as it allows parties to engage with and mobilize voters during and between elections. Research into this aspect of party organization in Africa has often been stymied, however, by the lack of systematic, reliable data, and the significant time and financial costs of collecting such data from scratch. Drawing on preexisting survey data from more than 30 countries, along with data from parties themselves, 
Krönke et al show that responses to questions about citizen-party engagement (a staple of many public opinion surveys) can be used to accurately measure both party presence and change at the grass roots, providing a valuable insight into the locations in which parties are active, and a rigorous new measure of local level party activity. In so doing, they allow us to rethink what party institutionalization looks like in the African context, and the ways in which this affects the political behavior of citizens, opening up a variety of important new research agendas.

Following this, the issue then shifts from the cross-national to the subnational level, and from a new measure of party presence to understanding what explains this party presence. Paget (“Lone Organizers: Opposition Party-Building in Hostile Places in Tanzania") begins this work by zeroing in on the Tanzanian context to understand where opposition parties choose to organize, and the different strategies they use to do so in a context of shrinking political freedom.

The literature suggests that opposition parties are most likely to organize where people are already receptive to their messages, and least likely to establish branches and recruit members in so-called "hostile areas", where people do not already trust or support the party. Paradoxically, therefore, the literature suggests that opposition parties are most likely to organize where they least need to, creating a challenge for parties that wish to expand and grow their base.

Drawing on 8 months of fieldwork, however, Paget shows that this is not always the case, and opposition parties, like Tanzania's Chadema, can and do organize in hostile areas. They do so, however, by relying on innovative party-building techniques, and a distinct set of political actors, which Paget terms "lone organizers". These lone organizers allow opposition parties to expand their geographic reach into hostile zones, by using personalized, mobile methods of communication. By convening repeated small rallies and meetings in areas with no party presence, that is, these individuals are able to overcome initial unreceptiveness to party 
messages, turning inhospitable zones into receptive areas over an extended period of time, and expanding the reach of the party in important ways.

Following Paget, Kwayu (“Determinants of a Political Party’s Social Media Strategy: A Comparative Analysis of Tanzania's Opposition Political Parties' Twitter Practices") continues this focus on party building in Tanzania, but moves from the physical world to the virtual realm of social media. Social media is, increasingly, an important form of party presence around the world, and one that has been significantly underexplored in the African context.

In her article, Kwayu asks what determines a political party's use of social media in increasingly autocratic contexts like that of contemporary Tanzania? Drawing on Twitter data for two opposition parties (Chadema and ACT-Wazalendo), along with interviews with party officials and social media influencers, Kwayu shows that the ways in which parties use social media depends on more than just the broad political context. That is, while the literature suggests that opposition parties in autocratic contexts are all likely to turn to social media in similar ways, Kwayu finds that party level factors, and specifically the level of institutionalization and resources, play an important role too - determining whether parties use social media primarily for mobilization, or in more complicated ways.

Having explored party organization on the ground and in the Twitter-sphere, the final two articles in this issue then move within the party, to explore the causes and consequences of candidate selection methods on party organization and electoral success.

Warren ("Democratizing Candidate Selection: Controlled Turnover in Botswana's Bulela Ditswe Primaries") begins this work by asking why political parties implement primary elections, giving up the authority to select their preferred candidates to a wider public. While previous work has argued that parties primarily institute primary elections to select for high 
quality candidates, incentivize campaigning efforts, and/or reduce intra-party conflict, Warren shows that senior party elites also implement mass primaries to induce limited and controlled legislator turnover in response to competitive electoral pressures. Using original data from Botswana's ruling party (the Botswana Democratic Party (BDP)), combined with qualitative and historical evidence, Warren argues that mass primaries provide a way for the BDP to bring in limited numbers of new, high valence candidates, while ensuring that senior elites are protected. In so doing, they prevent the party from appearing stale or captured, ensuring it is able to remain relevant and attractive to voters, while at the same time protecting senior ministers and party bigwigs from being ousted. They thus allow for a controlled turnover of political elites, providing an important way for electorally successful political parties, like the BDP, to safely replace unpopular and entrenched incumbents.

Finally, the fifth article in this issue, Sulley ("Democracy within Parties: Electoral Consequences of Candidate Selection Methods in Tanzania"), returns to the Tanzanian context to assess whether the ruling Chama Cha Mapinduzi (CCM) and opposition Chadema parties are really as different in terms of candidate selection methods as the literature has traditionally believed. Contrary to common arguments, she finds that candidate selection methods are very similar in both parties, challenging the long-held view that the ruling CCM nominates its candidates democratically, while the opposition does not. Instead, she finds that both parties have candidate selection methods that are, by design, undemocratic, with non-restrictive candidacy requirements, exclusive selectorates, and centralized selection and appointment, rather than the sort of democratic voting procedures explored by Warren. Drawing on textual analysis and qualitative in-depth interviews, moreover, Sulley also shows that these non-democratic selection 
rules have complicated effects on both democracy and party success, opening up important new research agendas in both the Tanzanian context, and the party literature more broadly.

\section{Conclusion}

Taken together, the contributions in this special issue advance the literature on party organization in Africa in a number of important ways. Various questions for further research remain, however. For example, our understanding of how parties organize at the local level, and the contextual factors that shape their presence, questions explored to some extent by all the authors, deserves further attention. How does a country's geography, level of urbanization, party system,

electoral system, and level of democracy affect parties' organizational density and party building efforts? To what extent do party building strategies differ between ruling and opposition parties (as well as among opposition parties)? And how do these dynamics affect processes of democratization and autocratisation?

Relatedly, further study of key intermediaries (such as Paget's lone organizers or Kwayu's social media influencers) has the potential to help us understand important elements of party building, intra-party democracy, and citizen-party engagement. How, for example, does the activity of intermediaries affect the sort of local party presence explored by Krönke et al? Which actors are most likely to successfully use the social media platforms discussed by Kwayu? And how might intermediaries affect the sort of intra-party democracy explored by Warren and Sulley? With regards to the latter, moreover, there is often an assumption that the formal rules governing political parties in Africa have limited impact on their behavior on the ground. Both Sulley and Warren cast some doubt on this assumption, however, and it would be interesting to study this further. 
Finally, all of the contributions to this special issue raise important questions about the consequences of party organization, and further research could fruitfully explore this in a variety of different contexts. How does intra-party democracy affect party building and electoral performance in different party systems, for example? To what extent will parties replace existing strategies, such as in-person canvassing, with the use of social media? And might this have different implications in democractic and autocratic regimes? What impact do lone organizers have once party-building is underway? And how does local party presence affect party success and support for democracy? We hope that the work in this issue will inspire future research to answer these and other questions, helping us to better understand the role of political parties in Africa, and informing related debates in other regions of the world as well. 


\section{References}

Aldrich J (1995) Why Parties? The Origin and Transformation of Political Parties in America. Chicago: University of Chicago Press.

Arriola LR (2012) Multi-Ethnic Coalitions in Africa: Business Financing of Opposition Election Campaigns. Cambridge: Cambridge University Press.

Arriola LR, Choi DD, Davis JM, et al. (2021) Paying to party: Candidate resources and party switching in new democracies. Party Politics. SAGE Publications Ltd: 1354068821989563.

DOI: $10.1177 / 1354068821989563$.

Barkan JD (1979) Politics and Public Policy in Kenya and Tanzania. New York: Praeger. Basedau M and Stroh A (2008) Measuring party institutionalization in developing countries: A new research instrument applied to 28 African political parties. Available at:

https://papers.ssrn.com/sol3/papers.cfm?abstract_id=1119203 (accessed 18 June 2017).

Bates RH (1971) Unions, Parties and Political Development: A Study of Mineworkers in Zambia. New Haven, CT: Yale University Press.

Berg-Schlosser D (2009) Long Waves and Conjunctures of Democratization. In: Haerpfer C, Bernhagen P, Inglehart RF, et al. (eds) Democratization. Oxford: Oxford University Press, pp. 41-53.

Bratton M (1980) The Local Politics of Rural Development: Peasant and Party-State in Zambia. Hanover, NH: University Press of New England.

Carothers T (2006) Confronting the Weakest Link: Aiding Political Parties in New Democracies. Washington D.C.: Carnegie Endowment for International Peace.

Chabal P and Daloz J-P (1999) Africa Works: Disorder as Political Instrument. Oxford: James

Currey.

Cheeseman N (ed.) (2018) Institutions and Democracy in Africa: How the Rules of the Game Shape Political Developments. Cambridge: Cambridge University Press.

Coleman JS and Rosberg CG (eds) (1964) Political Parties and National Integration in Tropical Africa. Berkeley, CA: University of California Press.

Cooper I (2018) Political Parties: Presidential Succession Crises and Internal Party Democracy. In: Cheeseman N (ed.) Institutions and Democracy in Africa: How the Rules of the Game Shape Political Developments. Cambridge: Cambridge University Press, pp. 191-212.

Doorenspleet R (2000) Reassessing the Three Waves of Democratization. World Politics 52(3): 384-406.

Elischer S (2013) Political Parties in Africa: Ethnicity and Party Formation. Cambridge University Press.

Frankel PH (1980) South Africa: The Politics of Police Control. Comparative Politics 12(4): 481-499.

Gertzel C, Baylies C and Szeftel M (eds) (1984) The Dynmics of the One-Party State in Zambia. Manchester: Manchester University Press.

Hodkin TL (1961) Political Parties in Africa. Baltimore: Penguin Books.

Jackson RH and Rosberg CG (1982) Personal Rule in Black Africa: Prince, Autocrat, Prophet, Tyrant. Berkeley, CA: University of California Press.

LeBas A (2011) From Protest to Parties: Party-Building and Democratization in Africa. Oxford: Oxford University Press.

Leys C (1967) Politicians and Policies: An Essay on Politics in Acholi, Uganda. Acholi, Uganda: East African Publishing House. 
Mackintosh JP (1962) Electoral Trends and the Tendency to a One-Party System in Nigeria. Journal of Commonwealth and Comparative Politics 1(3): 194-210.

Médard J-F (1982) The Underdeveloped State in Tropical Africa: Political Clientelism or NeoPatrimonialism. In: Clapham C (ed.) Private Patronage and Public Power: Political Clientelism in the Modern State. London: Frances Pinter, pp. 162-192.

Osei A (2013) Party System Institutionalization in Ghana and Senegal. Journal of Asian and African Studies 48(5): 577-593.

Pitcher MA (2012) Party Politics and Economic Reform in Africa's Demcoracies. Cambridge: Cambridge University Press.

Posner DN (2004) The Political Salience of Cultural Difference: Why Chewas and Tumbukas are Allies in Zambia and Adversaries in Malawi. American Political Science Review 98(4): 529545.

Posner DN (2005) Institutions and Ethnic Politics in Africa. New York, NY: Cambridge University Press.

Randall V and Svåsand L (2002) Political Parties and Democratic Consolidation in Africa. Democratization 9(3): 30-52.

Resnick D (2012) Opposition Parties and the Urban Poor in African Democracies. Comparative Political Studies 45(11): 1351-1378.

Riedl RB (2014) Authoritarian Origins of Democratic Party Systems in Africa. Cambridge:

Cambridge University Press.

Schachter-Morgenthau R (1964) Political Parties in French-Speaking West Africa. Oxford:

Clarendon Press.

Schattschneider EE (1942) Party Government. New York, NY: Rinehart.

Sklar RL (1963) Nigerian Political Parties: Power in an Emergent African Nation. Trenton, NJ: Africa World Press.

Wahman M (2017) Nationalized incumbents and regional challengers: Opposition- and incumbent-party nationalization in Africa. Party Politics 23(3): 309-322. DOI:

$10.1177 / 1354068815596515$. 